\title{
Energy-tax changes and competitiveness: The role of adaptive capacity
}

\author{
Camille Gonseth $^{\mathrm{a}, 1}$, Olivier Cadot ${ }^{\mathrm{b}, \mathrm{d}, 2}$, Nicole A. Mathys ${ }^{\mathrm{c}, \mathrm{e}, *}$, Philippe Thalmann ${ }^{\mathrm{a}, 3}$ \\ a École Polytechnique Fédérale de Lausanne, EPFL ENAC LEURE, Station 16, CH-1015 Lausanne, Switzerland \\ ${ }^{\mathrm{b}}$ Faculty of Business and Economics, University of Lausanne, CH-1015 Lausanne, Switzerland \\ c University of Neuchâtel, Rue A.-L. Breguet 2, CH-2000 Neuchâtel, Switzerland \\ d CEPR and FERDI., Bâtiment Internef, CH-1015 Lausanne, Switzerland \\ e Federal Office for Spatial Development, $\mathrm{CH}-3003$ Berne, Switzerland
}

\section{A R T I C L E I N F O}

\section{Article history:}

Received 5 January 2014

Received in revised form 8 September 2014

Accepted 4 December 2014

Available online 30 December 2014

\section{JEL classifications:}

Q48

Q58

D24

Keywords:

Energy taxes

Energy prices

Total factor productivity

Net trade

Porter hypothesis

\begin{abstract}
A B S T R A C T
This paper estimates the effect of energy tax (and price) changes on Total Factor Productivity (TFP) and net trade at the industry level, using a panel of industries from European countries covering the period 1990-2003. We investigate the hypothesis that industries with high adaptive capacity (measured by their relative level of labour compensation) are able to mitigate the adverse effects of energy tax rises better than others. We identify the pro-adaptation effect by interacting wage levels (a proxy for human capital) with energy taxes. We find that the negative marginal effect of higher energy taxes on TFP and net trade is significantly reduced for industries with stronger human capital and even turns to an overall positive effect in at least two cases. Up to three lowwage sectors display an overall negative effect. This suggests that human capital is key to adaptation to higher energy costs and climate policy, in some cases making it a win-win.
\end{abstract}

(C) 2014 Elsevier B.V. All rights reserved.

\section{Introduction}

Whereas opponents to the regulation of $\mathrm{CO}_{2}$ emissions often cite scientific uncertainty about the magnitude of climate-change risks, there is as much if not more uncertainty about the cost of cutting emissions. Technical change is at the heart of that uncertainty. As Jaffe et al. (2003, p.463) note, "[i]n global climate change modeling [...] different assumptions about autonomous improvements in energy efficiency are often the single largest source of difference among predictions of the cost of achieving given policy objectives." The uncertainty is not only about the magnitude of the cost of environmental regulation; there is also controversy about its sign. In influential articles, Porter (1991) and Porter and van der Linde (1995) argued that well-designed environmental regulation could be a spur to innovation, ultimately making regulated firms more competitive. Ambec et al. (2013) provide

\footnotetext{
* Corresponding author. Tel.: +4132718 13 56; fax: +41327181401.

E-mail addresses: cgonseth78@gmail.com (C. Gonseth), olivier.cadot@unil.ch

(O. Cadot), nicole.mathys@gmail.com (N.A. Mathys), philippe.thalmann@epfl.ch

(P. Thalmann).

1 Tel.: +4121693 72 97; fax: +41216933840.

2 Tel.: + 412169234 63; fax: + 41216923305 .

3 Tel.: +4121693 73 21; fax: +41216933840.
}

a recent review of theoretical and empirical insight on the Porter Hypothesis (PH). They distinguish between behavioural arguments, market failures (market power, asymmetric information, research and development (R\&D) spillovers) and organizational failure (see for example Ambec and Barla, 2002).

Arguments similar to the Porter Hypothesis were made by DeCanio (1993) and Lovins (1996). Building on the "evolutionary" tradition of the economics of R\&D (Nelson and Winters, 1982) which views firms as boundedly rational, Gabel and Sinclair-Desgagné $(1993,2001)$ proposed a model in the same vein, in which the enforcement of environmental regulation overcomes organizational failures within firms, leading them to become more efficient overall. Later attempts at formalizing the Porter Hypothesis (e.g. Ambec and Barla, 2002; Mohr, 2002) based the argument on market failures other than environmental externalities (barriers to innovation - network externalities, lock-in effects, or imperfect information - or external economies of scale in production), behavioural or organizational failures. Attributing a strategic role to technology adoption Mohr (2002) introduces external economies of scale in production. The productivity of any given agent depends on the cumulative production experience of all agents using the same technology. In this setting external economies of scale can explain why firms might rationally avoid the short-term cost of experimenting with new technologies. Environmental policy could therefore indeed 
offset a coordination failure. Ambec and Barla (2002) argue that environmental regulation allows firms to overcome organizational inertia (e.g. private information of managers about real costs of new technologies that might be used to extract rents from the firm).

While theoretical arguments are sound, the evidence, reviewed in Section 2 of this paper, is largely ambiguous. One of its key insights, which came out in an important recent paper (Commins et al., 2011), is that the effect of energy-tax shocks varies substantially across sectors. These results suggest that aggregate effects of environmental policy changes are likely to hide substantial cross-sectoral heterogeneity.

We build on this literature and extend it by looking for factors driving adaptability at the industry level, more precisely focusing on the role of human capital. The intuition is that if adaptation requires technical innovation or the reorganization of production processes, the availability of human capital is likely to help. Suppose e.g. that firms face costs to implement energy-efficiency programs helping them to reduce energy costs. Sectors with skilled workforces will have less difficulty implementing such programs and will see their performance deteriorating less as a result of higher energy prices. In addition to facilitating direct adaptation at the firm level, human capital may also facilitate the diffusion of best practices (e.g. Battisti et al., 2009).

Specifically, our approach analyses the response of industry TFP to changes in energy taxes and prices (net of taxation). Our dependent variable is TFP constructed either as an index or through estimation via a production-function approach. Results are similar under the two approaches. ${ }^{4}$ In robustness runs, we also use net trade as a measure of competitiveness at the industry level. Our unit of observation is a country-sector-year combination where sectors are defined by the OECD's STAN database.

Our central hypothesis is that the effect of high energy prices on industry TFP is affected by the industry's capacity to adapt. Like Commins et al. (2011), our identification strategy relies on the cross-industry variation in how energy taxes and prices affect performance. In order to identify the effect of human capital, we interact energy taxes and prices with industry-level relative wages.

Our sample used is a panel of industry $\times$ country pairs tracked over the period 1990-2003 from the OECD's STAN database, comparable to the data used by Enervoldsen et al. (2009). Working at the industry level has advantages and drawbacks. On the one hand, identification is obviously not as sharp as in Commins et al. (2011) who perform their analysis at the firm level. On the other hand, TFP improvements at the firm level can be obtained by "passing the buck" of adjustment to either customers or suppliers. For instance, energy-intensive operations could be outsourced, producing TFP gains at the firm level that have no counterpart at the aggregate level and whose offsets would be difficult to track. Working at the industry level allows us to "internalize" at least some of these spillovers, although not those with an international dimension.

Our main regressors of interest, energy taxes and prices, are country $\times$ year specific. This might lead to overestimate the energy taxes faced by certain industries, mostly energy-intensive ones, given the possibility of exemptions which can be attributed. Data limitations do not allow us to dig deeper into this issue. Some recent papers on the response of gasoline consumption to a change in taxes also suggest that the short run economic impact of introducing or tightening energy or $\mathrm{CO}_{2}$ taxes is not equivalent to that of rising fossil-fuel prices (Baranzini and Weber 2013; Davis and Kilian, 2011; Li et al., 2012). While price changes due to policy intervention are seen to be rather permanent and less volatile, market price changes can be seen as transitory phenomena. We deal with this by explicitly separating the effect of energy prices (net of taxation) from energy taxes.

We control for heterogeneity at the industry level using both timevariant and time-invariant industry characteristics. The latter are

\footnotetext{
${ }^{4}$ Results with the index-based TFP derivation are available upon request.
}

represented by a full set of industry $\times$ country fixed effects. We also include year dummies, which are not collinear with energy prices and taxes due to country-specific evolution of both exchange rates and energy taxation.

As a robustness test, we also apply the approach proposed in Rajan and Zingales (1998) and subsequent papers. That is, we eliminate the energy price variable and instead include a full set of country $\times$ year effects. This approach makes it impossible to estimate the absolute effect of energy-price changes, but it identifies their differential effect across industries.

We find that the marginal effect (ME) of energy taxes on TFP (and net trade in the robustness runs), while being negative for low-wage sectors, becomes gradually positive for sectors with higher wage levels. At high wage levels, the tendency is sufficiently strong to produce significant positive MEs for some industries and countries. Thus, some industries seem to react so strongly to energy-tax shocks that their TFP ends up higher, in conformity with the Porter Hypothesis.

The paper is organized as follows. Section 2 reviews the empirical literature, Section 3 presents our estimation strategy and the data. Section 4 presents and discusses results and robustness runs. Section 5 concludes.

\section{Environmental regulation and economic efficiency: What do we know?}

The existing evidence on the PH, surveyed, inter alia, in Jaffe et al. (2003) and Vollebergh (2006), is at best a half-full half-empty bottle. Jaffe et al. (1995) reviewed 16 empirical studies of the effects of environmental regulation on competitiveness in the US manufacturing sector, and concluded that "[...] there is relatively little evidence to support the hypothesis that environmental regulations have had a large adverse effect on competitiveness, however that elusive term is defined" (p.157). Albrecht (1998) found that early adoption of Montreal Protocol measures (CFC phase-out) by the US and Denmark did not affect the competitive position, measured through bilateral trade positions, of refrigerator and industrial-cooler producers; however, early adoption is likely to have been endogenous to the outcome. Snyder et al. (2003) studied the effect of chlorine regulation on a panel of US chlorine manufacturing plants over 1976-2001. They found that adopting plants had a lower probability of exit than non-adopting ones, although the $\mathrm{PH}$ is about the absolute performance of regulated firms, not about the relative performance of adopting vs. non-adopting firms. In the same vein, Murti and Kumar (2003) found some evidence of better performance by firms that also had a better environmental compliance record among a panel of 92 Indian manufacturing plants. Lanoie et al. (2008) constructed a sector-specific measure of the stringency of environmental regulation for a panel of manufacturing sectors in Québec and found that, while current regulatory stringency reduced productivity growth, lagged stringency raised it, suggesting learning and adaptation effects. Enervoldsen et al. (2009) estimated the impact of energy prices on gross value added for a panel of European industrial sectors and found that while they had a moderate negative impact on output via higher unit energy and labour costs, they also had a relatively strong direct impact on output, which they interpret as evidence that energy taxes stimulate product innovation, which in turn raises demand for their products.

So much for the half-full bottle. As for the half-empty, Palmer et al. (1995) surveyed firms affected by environmental regulation, including those cited by Porter and van der Linde (1995) as success stories, and found that most firms declared that regulation was a net cost (see also Joshi et al., 1997; Morgenstern et al., 1999). However, that managers would complain about environmental regulations in interviews might not come as a surprise. Becker and Henderson (2000) found that plant births at the country level were reduced by current regulatory stringency proxied by low attainment status under the Clean Air Act. Lanoie et al. (2011) used a recent OECD cross-country firm-level survey to regress 


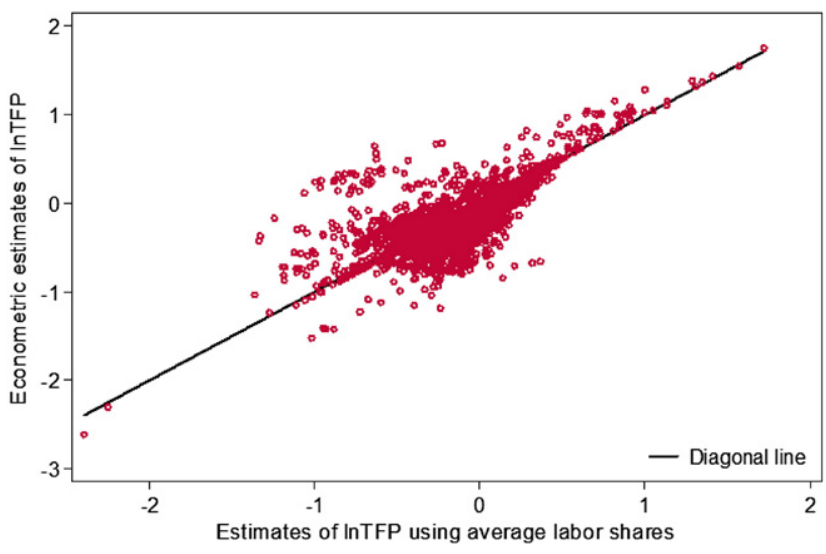

Fig. 1. Comparison of two measures of InTFP: index and residual-based.

environmental-R\&D status (do environmental R\&D = 1) and a subjective (self-assessed) index of business performance on firm characteristics and a measure of environmental regulation stringency. They found that environmental stringency raised the probability of doing environmental R\&D but had a negative effect on selfassessed performance.

The effect of energy prices and taxes on TFP and innovation has been studied by yet another substantial literature, with, again, ambiguous results. Berndt and Wood (1986) found that rising energy prices in the 1970s and 80s contributed to the productivity slowdown. Rose and Joskow (1990) found no significant effect of fuel prices on the adoption of a new fuel-saving technology in the US electricity-generation sector. By contrast, Jaffe and Stavins (1995) looked at the adoption of thermal insulation in residential construction in the US between 1979 and 1988 and found a positive and significant response of mean energy efficiency to energy-price changes. Interestingly, they found a larger response to changes in adoption costs than to changes in energy prices, possibly suggesting credit constraints. Finally (although this list is by no means exhaustive), Popp (2002) finds that higher energy prices raise patenting activity in energy-related fields, although the effect fades over time. Thus, in spite of a voluminous literature, the effect of energy prices on innovation and productivity is still very much an open question.

Part of the problem with the PH is that it is cast in characteristically loose terms, in particular as regards "competitiveness", a term with which economists have difficulty. In addition to the paper already cited above by Lanoie et al. (2008), a number of other papers have looked at the effect of environmental regulation on Total Factor Productivity (TFP) growth. Again, the evidence is conflicting. Gollop and Roberts (1983) constructed a firm-specific measure of regulatory stringency in the electric-power industry and found that emission regulations significantly raised generating costs, reducing the average rate of productivity growth by 0.59 percentage points per year for constrained utilities. Gray and Shadbegian (1998) found that pollution abatement investments crowded out productive investments almost entirely in the pulp \& paper industry. Greenstone (1998) found that air-pollution regulation had a slight positive effect on unit costs, implying a small negative effect on productivity. On the other hand, Berman and Bui (2001) found significant productivity increases associated with airpollution regulation on a sample of oil refineries. Shadbegian and Gray (2005) failed to find a negative correlation between abatement costs and productivity, although they did not find a positive one either.

Recently, Commins et al. (2011) used a panel of European firms taken from the AMADEUS database to analyse the impact of energy taxes on firm characteristics such as changes in TFP, employment levels, return on capital and investment. The sample covers the period 19962007. They interacted country energy taxes with sectoral dummies to obtain sector-specific effects. Depending on sectors, they identified negative, positive or non-significant effects of energy taxes on TFP.

Another strand of the literature has looked at the relationship between environmental regulation and innovation. This is particularly important as technical change is both a factor of uncertainty in the costs of future environmental regulations and a likely causal link alongside improved managerial efficiency-relating regulation to improved "competitiveness". Lanjouw and Mody (1996) showed, on a panel of countries over 1971-88, that higher pollution abatement costs (as a \% of GDP) led to a higher share of environmental patents in the country's total patent count with a one to two years delay. Jaffe and Palmer (1997) showed, on a panel of US industries between 1974 and 1991, that lagged abatement expenditure is positively correlated with current R\&D spending, although not with patenting activity. By contrast, Brunnermeier and Cohen (2003) found a significant and positive correlation between (contemporaneous) abatement expenditure and successful environmental patent applications. Hence, the empirical evidence of the effect of environmental regulation on patent activity, which is clearly also only an imperfect measure of innovation, is so far rather positive.

There exists also a sizable literature on the diffusion of innovation that identifies determinants of the adoption of new technologies (for a review, see Hall, 2006). The main determinants can be grouped into firm and industry characteristics, the extent of usage of the technology in the industry or by similar firms, adoption costs, and inducement effects such as prices and taxes or public incentives and regulation. When looking at adoption at the level of industries, the epidemic effect (spread by contact) plays a lesser role and industry characteristics a greater one. Worker skill levels regularly emerge as a determining characteristic (Hall and Khan, 2003, who refer this observation back to Rosenberg, 1972). When skills are insufficient for uptake, suppliers of new technologies offer training to increase it. A broad, albeit imperfect, indicator of the skill level is the relative level of wages in the industry. Skills (or education or human capital) are not the only determinant of relative wages, yet they play a dominant role. Edin and Zetterberg (1992) showed that human capital is more than ten times more important than industry variables in explaining wage differentials in Sweden. Gibbons et al. (2005) showed both theoretically and empirically that high-wage sectors employ high-skill workers and offer high returns to workers' skills. Estimates by Kniesner and Leeth (1991) show only little effects of the riskiness of jobs on average wage levels. A related effect of skill levels on the impact of higher energy prices might operate through R\&D: industries with higher human capital tend to be better able to respond by intensifying research. But this is not the whole story. One expects that many adjustment activities are not reflected in $R \& D$ statistics but rather consist of small optimisation activities.

The main contribution of the present paper to the literature is that we test whether the effect of taxes and energy prices on TFP and net trade can be mediated through adaptive capacity, proxied by relative wage levels. This is novel and has not been investigated so far.

\section{Material and methods}

\subsection{Empirical methodology}

As introduced above, we measure industry-country performance by a total factor productivity (TFP) measure. Let $K_{i c t}$ be sector $i$ 's capital stock in country $c$ at time $t, L_{i c t}$ its labor input, $Y_{i c t}$ its measured value added, and $\bar{\alpha}_{i c}$ the average share of capital in the value added of sector $i$ in country $c$ over the sample period. Lacking disaggregate data other production factors (e.g. human capital) are excluded from the analysis. The data is taken from the OECD STAN database. Energy and other intermediate inputs (material) are excluded from this first estimation as we focus on value added instead of output. The TFP index is then defined 
Table 1

Changes in energy prices incl. taxes for the time period 1990-2003.

\begin{tabular}{lcccc}
\hline \multirow{2}{*}{ Country } & \multicolumn{3}{l}{$\%$ change in the price of automotive diesel: $(\Delta \mathrm{p} / \mathrm{p})^{*} 100$} \\
\cline { 2 - 4 } & \multicolumn{2}{l}{ Annual percentage change } & $\begin{array}{l}\text { Total change over } \\
\text { time period }\end{array}$ \\
\cline { 2 - 4 } & Min & Max & Median & \\
\hline Belgium & -8.6 & 24.9 & 3.8 & 43.3 \\
Czech Rep. & -13.2 & 53.1 & 0.5 & 83.2 \\
Denmark & -3.0 & 40.4 & 7.0 & 187.2 \\
Finland & -21.2 & 24.7 & 1.9 & 5.9 \\
France & -5.4 & 23.7 & 2.0 & 45.4 \\
Italy & -5.0 & 20.9 & 4.5 & 73.2 \\
\hline
\end{tabular}

Note: Annual percentage change in the net consumer price of automotive diesel faced by the industrial sector. The last column gives the percentage change in the net consumer price of automotive diesel for the time period 1990-2003. Source: IEA.

by:

$T F P_{i c t}=\frac{Y_{i c t}}{K_{i c t} \bar{\alpha}_{i c} L_{i c t}{ }^{1-\bar{\alpha}_{i c}}}$

Taking the natural logarithm of both sides of Eq. (1) gives us:

$\ln T F P_{i c t}=\ln Y_{i c t}-\bar{\alpha}_{i c} \ln K_{i c t}-\left(1-\bar{\alpha}_{i c}\right) \ln L_{i c t}$

As is apparent from Eq. (2), productivity can also be calculated while estimating the coefficients of a constrained panel production-function such as:

$$
\begin{aligned}
& \ln Y_{i c t}=\alpha_{1} \ln K_{i c t}+\left(1-\alpha_{1}\right) \ln L_{i c t}+\eta_{i c}+\mu_{t}+\varepsilon_{i c t} \\
& \ln T \hat{F} P_{i c t}=\ln Y_{i c t}-\hat{\alpha}_{1} \ln K_{i c t}-\left(1-\hat{\alpha}_{1}\right) \ln L_{i c t}
\end{aligned}
$$

where $\varepsilon_{i c t}$ is assumed to be normally distributed with zero mean and constant variance, $\eta_{i c}$ is an industry $\times$ country fixed effect and $\mu_{t}$ is a year effect. $\alpha_{1}$ has been estimated using a constrained OLS estimator after having first-differentiated the data.

Fig. 1 shows a scatter plot of TFP estimates (in logs) calculated from Eq. (2) (on the horizontal axis) and from Eq. (4) (on the vertical axis). It can be seen that results are coherent (i.e. close to or on the diagonal) although there is also substantial variation.

Both methods are used in the literature to compute TFP. Qualitatively, the choice between the two methods has no impact on our main findings. For the sake of brevity, estimates reported throughout this paper are based on estimation of Eq. (4) TFP measures.

In the second step, we use our TFP estimates or net trade (the log of the exports to imports ratio) as the dependent variable in an equation where energy taxes and energy prices (net of taxes) are the key explanatory variables introduced, linearly and interacted with a measure of relative labour compensation. Specifically we have:

$$
\begin{aligned}
\ln T \hat{F} P_{i c t}= & \beta_{0}+\beta_{1} \ln P_{c t}+\beta_{2} \ln w_{i c t}+\beta_{3}\left(\ln P_{c t} \times \ln w_{i c t}\right) \\
& +\gamma^{T} \mathbf{X}_{i c t}+\delta_{i c}+\delta_{t}+u_{i c t}
\end{aligned}
$$

where $P_{c t}$ is the tax of energy (and similarly the energy user price net of taxes introduced simultaneously) in country $c$ and year $t, w_{i c t}$ is industry $i$ 's labour compensation per employee relative to the manufacturing average in country $c$ and year $t$ (permanent inter-industry differences in skills are picked up by industry $\times$ country dummies), $\mathbf{X}_{i c t}$ is a vector of control variables (in logs) at the industry $\times$ country $\times$ year level, $\delta_{i c}$ is a fixed effect at the industry $\times$ country level, and $\delta_{t}$ is a year dummy and $u_{i c t}$ is the error term, normally distributed with zero mean and constant variance. All data are deflated by industry-specific price indices and converted to U.S. dollar values. As a result, all variables are expressed in base year 2000 U.S. dollars.

In spite of inflation adjustment, movements in measured TFP may pick up insufficiently controlled movements in prices as well as quantities produced and therefore reflect changes in industry structure or market power. As discussed in Section 3.2.3, additional control variables are introduced in the vector $\mathbf{X}_{i c t}$ to capture these effects.

Estimation is by OLS and we allow for an arbitrary covariance structure over time by clustering standard errors at the industry $\times$ country level. In a robustness exercise, we estimate Eq. (5) by GMM in order to control for persistence in TFP and for endogeneity of the R\&D spending, import-penetration and export share of production variables.

\subsection{Data}

\subsubsection{Data sources and coverage}

We use a panel data set that covers 11 manufacturing sectors (classified at the 2 digit level ISIC Rev. 3) in 6 European countries (Belgium, Czech Republic, Denmark, Finland, France and Italy) over 1990-2003, yielding a sample size of almost 500 observations. Given the need to measure productivity from a set of industrial data and to combine this

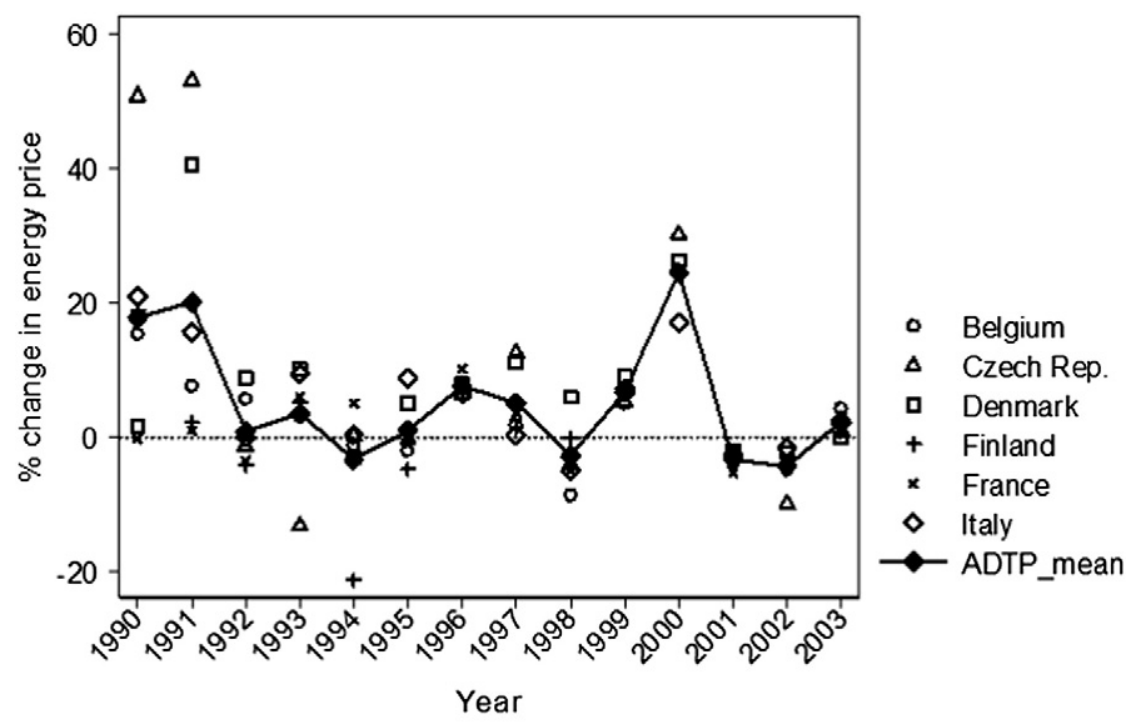

Source:IEA.

Fig. 2. Changes in total energy prices for automotive diesel. 
Table 2

Country-level taxation of automotive diesel for the period 1990-2003.

\begin{tabular}{|c|c|c|c|c|}
\hline \multirow[t]{2}{*}{ Country } & Tax wedge in $1990(\%)$ & Tax wedge in 2003 (\%) & Tax change over the period 1990-2003 (\%) & Incentive taxes affecting automotive diesel price \\
\hline & (a) & (b) & $(c)$ & $(d)$ \\
\hline Belgium & 46.8 & 47.0 & 44.1 & - \\
\hline Czech Rep. & 55.1 & 45.4 & 50.9 & - \\
\hline Denmark & 0 & 50.7 & $395.5^{\mathrm{a}}$ & $\mathrm{CO}_{2} \operatorname{tax}(1992)$ \\
\hline Finland & 58.7 & 48.2 & -13.1 & $\begin{array}{l}\mathrm{CO}_{2} \text { tax }(1990) \\
\text { Excise Taxes for sulphur content }(1987,1995)\end{array}$ \\
\hline France & 57.5 & 59.1 & 49.6 & - \\
\hline Italy & 60.0 & 55.1 & 59.3 & $\mathrm{CO}_{2} \operatorname{tax}(1999)$ \\
\hline
\end{tabular}

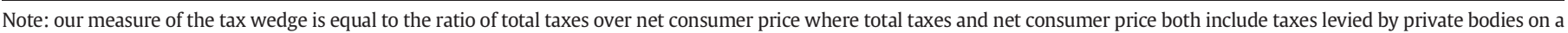

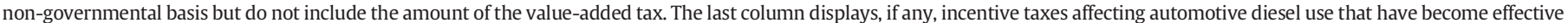
or that have been changed during the time period (the number in brackets is the year of introduction of the tax). Source: IEA, INFRAS (2007). ${ }^{\mathrm{a} C o m p u t e d ~ o v e r ~ t h e ~ p e r i o d ~} 1991-2003$.

industrial performance measure with data on labour compensation and other control variables, this sample is the largest possible dataset that we could obtain. Our sample has the advantage that these countries have close economic and institutional structures, trade heavily with each other and share similar cultural and economic values, which in turn reduces unobserved heterogeneity in the data. The flip side of the coin is that our estimation will be restricted to data with limited variation. This means that it will be more difficult to identify significant effects, but if we find them, then we can be more confident. However, it also somewhat limits the external validity of our results, as extrapolation to countries with characteristics very different from European countries would be difficult.

We use the Energy Prices and Taxes database of the International Energy Agency (IEA) and follow Kilian (2008) by selecting prices and taxes directly relevant to economic agents instead of using information on crude oil. We use the price of automotive diesel, one important type of energy use in industry and most importantly the most complete price and tax data for our sample. ${ }^{5}$ In addition, as a robustness test, we also use natural gas taxes and prices.

\subsubsection{Energy prices $(A D P)$ and taxes $(A D T)$ : stylized facts}

Table 1 reports changes in energy prices (including taxes) for automotive diesel in local currency units for the countries in our sample over the period 1990-2003. It can be seen that there is substantial variation in energy prices over the sample period, both over time and across countries. A clear upward trend of total energy prices can however be identified. While Italy, the Czech Republic and Denmark report large increases, energy prices in Finland increase much less.

Fig. 2 shows the changes in energy prices over time in detail. Two main periods of increasing energy prices can be identified. The first one at the beginning of the nineties, where two countries introduced for the first time energy and carbon taxes with environmental objectives (cf. Table 2) and a second one, around 2000, where all countries see their energy prices increase.

Energy taxation is one determinant of energy prices. The Porter Hypothesis works through policy intervention and not market prices. As discussed in the introduction, empirical studies indeed also found that energy consumers react differently to endogenous price changes than to price changes induced through policy intervention. We are therefore mainly interested in variations in energy taxes. Table 2 and Fig. 3 display changes in energy taxes for automotive diesel in local currency units (ADT) for our sample.

All countries except Finland see their energy taxes also increase over the sample period, with the most important increase in Denmark which

\footnotetext{
${ }^{5}$ We refrain from using a quantity weighted average price/tax not only because of limited data availability for the other price and tax series, but also for the fact that this would introduce additional endogeneity, as the fuel mix is expected to be the results of the behavioral adaptation of firms.
}

is due to the absence of any tax in 1990. In the early 1990s the countries in our sample, which were among the first to introduce environmentally motivated energy taxes, raised their taxes on automotive diesel for environmental purposes and again at the end of the 1990s. The effect of environmental policy changes on industry-level TFP and net trade revealing relevant information for the debate on the economic cost of environmental regulation is investigated in Section 4.

\subsubsection{Additional control variables}

To control for other factors that determine TFP and net trade and are not captured by the two sets of year and industry $\times$ country fixed effects, we introduce additional variables, most of which are taken from the OECD STAN database (data sources are given in Table A1 of the appendix). As suggested in earlier studies, we include lagged R\&D expenditures (R\&D spendings) which we expect to have a positive effect on TFP and net trade (e.g. Griffith et al, 2004). The lag aims at avoiding simultaneity bias between contemporaneous TFP and R\&D spending. Two variables - export share of production (Export Share) and import penetration (computed as the ratio of imports to total domestic demand, Import Pen.) - measure the intensity of international competition in each sector (e.g. Nickell, 1996). They are included as controls for unobserved components of competitiveness with positive expected coefficients as more competition should spur productivity. ${ }^{6}$ Moreover we expect competition within a sector, measured by the number of establishments (Nbr. of Estab), to influence our measure of TFP and net trade. As a robustness test we also us the price-cost margin ( $\mathrm{PCM}$ ) as analysed by Boulhol (2008). ${ }^{7}$ If competition spurs productivity, a negative coefficient should be observed, if market power spurs productivity, a positive coefficient should be observed. We also include exchange rates (expressed as local currency per US\$, US Exch. Rate) because their movements might affect mark-ups via changes in import or export prices of final goods, as well as energy and other imported input prices (e.g. Copeland and Kahn, 2012). The expected effect of exchange rates depends on the relationship between imported inputs and exported final goods within industries. Finally, the inclusion of the value of output (Output) allows capturing effects of scale economies on productivity (e.g. Nickell, 1996). A positive coefficient is expected for this variable.

\section{Results}

This section discusses regression results on the relationship between energy taxes and industry-level productivity. Section 4.1. presents the main results of the effect of automotive diesel taxes on industry TFP, while Section 4.2. shows several robustness tests, mainly using an alternative energy price variable (natural gas) or net trade as the

\footnotetext{
6 These variables are not included in the net trade regressions, since the dependent variable is already constructed using import and export data. Including these variables would not add insights and lead to tautological relations.

7 We thank an anonymous referee for pointing out this measure.
} 


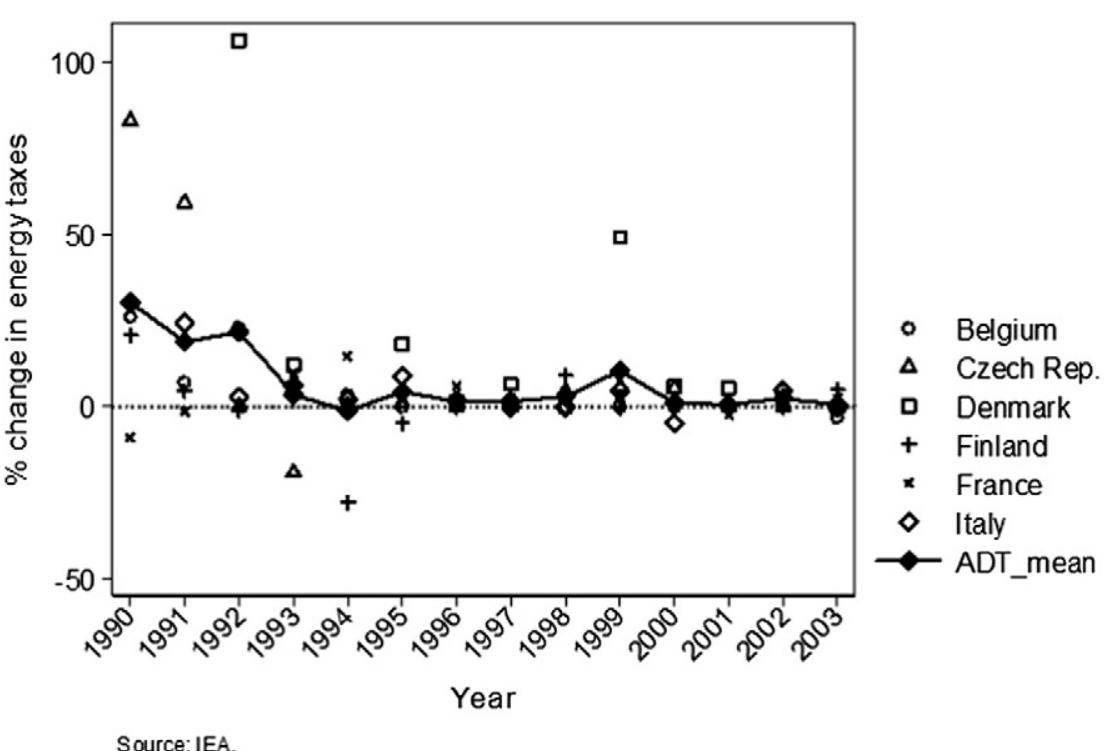

Fig. 3. Changes in automotive diesel taxation over the sample period 1990-2003.

dependent variable. Given the inclusion of interaction terms, marginal effects must be computed to show the differentiated impact of energy tax increases on competitiveness measures of sectors with different adaptive capacity. Section 4.3. displays and discusses the marginal effects.

\subsection{Energy tax effects on productivity: baseline results}

Random effects (RE), fixed effects (FE) and Difference GMM estimation results for Eq. (5) are shown in Table 3. All t-statistics are corrected for heteroskedasticity and autocorrelation.

The FE estimator allows us to control for unobserved heterogeneity among industry $\times$ country combinations and the Hausman test rejects the hypothesis of equality of coefficients for the RE and FE estimations (column (1) vs. (2)), so estimates obtained from the latter should be preferred. The sharp increase in the reported R-squared from column (1) to (2) also confirms that the fixed effects are covering a large amount of total variation of the dependent variable by controlling for unobserved heterogeneity among industries and countries. The fixed effect estimation in column (2) is therefore our preferred specification. In column (3), the approach by Rajan and Zingales (1998) is used and sets of country $\times$ year and industry fixed effects are used. Column (4) reports estimates with GMM in first differences ${ }^{8}$ allowing the introduction of the lagged dependent variable and to account for the possible endogeneity of explanatory variables. Given the limited sample at hand (both panel dimensions are rather small), one should take these results with caution.

Automotive diesel tax (ADT) and price (ADP) have a negative direct effect on TFP while their interactions with labor compensation have a positive effect on TFP. The interaction term of labor compensation with taxes is significant in the RE and FE estimations, while the interaction term with energy prices is significant in the GMM specification.

Among the coefficients on control variables, scale has the expected and significant effect. Exchange rates display mostly a positive and significant one. The number of establishments has a negative effect on TFP in columns (1)-(3) indicating that concentrated sectors report higher TFP. The export share of production and import penetration display mainly non-significant coefficients. Except in the FE estimations, where a significant negative effect of the export share on TFP

\footnotetext{
8 System GMM results have also been computed but given the small sample size, results are globally insignificant and not reported.
}

is displayed. This is not as expected and might be explained by the strong correlation between the trade variables (correlation coefficient of 0.75 ) as well as endogeneity issues, which is why both variables are instrumented with their suitable lags in the GMM estimation.

\subsection{Robustness tests}

Table 4 and taxes for natural gas are used, while columns (2) to (5) stick with the automotive diesel energy carrier but use net trade instead of TFP as dependent variable or the price-cost margin instead of the number of establishments to measure competition in the sector. Column (5) reports the Rajan and Zingales (1998) estimation for net trade. Note that in the net trade case, our preferred estimation is the RE given in column (3), since the Hausman test allows us to focus on the more efficient RE estimator. In all cases, except for the estimation with country*year fixed effects in column (5) the coefficient on the interaction term between energy taxes and adaptive capacity, is positive and highly significant. With few exceptions, other effects are qualitatively unchanged. The coefficient on the price-cost markup is positive and significant. It suggests that in the present framework market power leads to higher TFP. In columns (1), and (3)-(5) the interaction term on energy prices (net of taxes) also displays a significant positive interaction term with our measure for adaptive capacity. At the exception of column (5), it is however always smaller and less significant than the coefficient for taxes. Overall, previous results are confirmed. Estimated coefficients associated to the variables interacting energy taxes (and to some extent prices) with labor compensation are positive. These positive coefficients suggest that the negative effect of energy tax and price shocks might be mitigated by the adaptive capacity of industries with relatively highly qualified workers. This is in line with theory while at the same time reflecting the differentiated effects across sectors. In order to assess the overall impact of energy taxes on industries, the marginal effects are displayed and discussed in the next section.

\subsection{Marginal effects for TFP and net trade}

Fig. 4 for automotive diesel and TFP, Fig. 5 for automotive diesel and net trade and Fig. 6 for natural gas and TFP display the marginal effects (MEs) together with their 95\% confidence intervals. ${ }^{9}$ They are computed

\footnotetext{
${ }^{9}$ Calculated using the nlcom command of Stata.
} 
Table 3

Regression estimates: In TFP as dependent variable.

\begin{tabular}{|c|c|c|c|c|}
\hline \multirow[t]{2}{*}{ Variables } & \multirow{2}{*}{ 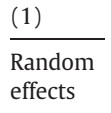 } & \multirow{2}{*}{$\begin{array}{l}(2) \\
\text { Fixed } \\
\text { effects }\end{array}$} & \multirow{2}{*}{$\begin{array}{l}(3) \\
\text { Fixed } \\
\text { effects }\end{array}$} & \multirow{2}{*}{$\begin{array}{l}(4) \\
\text { Diff. } \\
\text { GMM }\end{array}$} \\
\hline & & & & \\
\hline \multicolumn{5}{|l|}{ Dependent variable: In TFP } \\
\hline 1.ln TFP & & & & $\begin{array}{l}0.40^{* *} \\
{[0.16]}\end{array}$ \\
\hline In Export Share & $\begin{array}{l}-0.072 \\
{[0.060]}\end{array}$ & $\begin{array}{l}-0.24^{*} \\
{[0.12]}\end{array}$ & $\begin{array}{l}-0.10^{* * *} \\
{[0.032]}\end{array}$ & $\begin{array}{l}-0.32 \\
{[0.25]}\end{array}$ \\
\hline In Import Pen. & $\begin{array}{c}-0.12 \\
{[0.086]}\end{array}$ & $\begin{array}{l}-0.12 \\
{[0.17]}\end{array}$ & $\begin{array}{l}0.022 \\
{[0.048]}\end{array}$ & $\begin{array}{l}-0.26 \\
{[0.36]}\end{array}$ \\
\hline In Labour comp. & $\begin{array}{l}1.28^{* *} \\
{[0.54]}\end{array}$ & $\begin{array}{l}1.60 * * \\
{[0.66]}\end{array}$ & $\begin{array}{l}0.47^{*} \\
{[0.28]}\end{array}$ & $\begin{array}{l}0.22 \\
{[0.82]}\end{array}$ \\
\hline 1.In R\&D spendings & $\begin{array}{l}0.061 \\
{[0.040]}\end{array}$ & $\begin{array}{l}0.049 \\
{[0.037]}\end{array}$ & $\begin{array}{c}-0.032 \\
{[0.020]}\end{array}$ & $\begin{array}{l}0.015 \\
{[0.028]}\end{array}$ \\
\hline In Output & $\begin{array}{l}0.12^{* * *} \\
{[0.048]}\end{array}$ & $\begin{array}{l}0.44^{* * *} \\
{[0.10]}\end{array}$ & $\begin{array}{l}0.22^{* * *} \\
{[0.057]}\end{array}$ & $\begin{array}{l}0.34^{* * * *} \\
{[0.13]}\end{array}$ \\
\hline In Nbr. of Estab. & $\begin{array}{l}-0.061^{*} \\
{[0.032]}\end{array}$ & $\begin{array}{l}-0.024 \\
{[0.023]}\end{array}$ & $\begin{array}{l}-0.078^{* * *} \\
{[0.029]}\end{array}$ & $\begin{array}{l}0.0019 \\
{[0.025]}\end{array}$ \\
\hline In US Exch. Rate & $\begin{array}{l}0.14^{* * *} \\
{[0.052]}\end{array}$ & $\begin{array}{l}0.85^{* * *} \\
{[0.25]}\end{array}$ & & $\begin{array}{l}0.58^{*} \\
{[0.30]}\end{array}$ \\
\hline $\ln \mathrm{ADT}$ & $\begin{array}{l}-5.89^{* * *} \\
{[1.58]}\end{array}$ & $\begin{array}{l}-6.53^{* * *} \\
{[1.95]}\end{array}$ & & $\begin{array}{l}-1.11 \\
{[1.98]}\end{array}$ \\
\hline $\ln \mathrm{ADP}$ & $\begin{array}{l}-0.40 \\
{[1.05]}\end{array}$ & $\begin{array}{l}-1.40 \\
{[1.01]}\end{array}$ & & $\begin{array}{l}-2.14^{* * *} \\
{[0.73]}\end{array}$ \\
\hline ln ADT × ln Labour comp. & $\begin{array}{l}1.24^{* * *} \\
{[0.34]}\end{array}$ & $\begin{array}{l}1.41^{* * * *} \\
{[0.42]}\end{array}$ & $\begin{array}{l}0.55^{* *} \\
{[0.23]}\end{array}$ & $\begin{array}{l}0.23 \\
{[0.42]}\end{array}$ \\
\hline In ADP $\times$ ln Labour comp. & $\begin{array}{l}0.13 \\
{[0.23]}\end{array}$ & $\begin{array}{l}0.31 \\
{[0.23]}\end{array}$ & $\begin{array}{l}0.13 \\
{[0.14]}\end{array}$ & $\begin{array}{l}0.41^{* *} \\
{[0.16]}\end{array}$ \\
\hline Industry FE & no & no & yes & no \\
\hline Country FE & no & no & no & no \\
\hline Industry $\times$ Country FE & no & yes & no & yes \\
\hline Country $\times$ Year FE & no & no & yes & no \\
\hline Year FE & yes & yes & no & yes \\
\hline Observations & 466 & 466 & 466 & 343 \\
\hline R-squared & 0.040 & 0.851 & 0.591 & \\
\hline Prob > chi2 (Hausman test) & & $<0.0001$ & & \\
\hline Prob $>\mathrm{z}$ (test $\mathrm{AR}(1)$ in levels) & & & & 0.671 \\
\hline Prob $>\mathrm{z}$ (test $\mathrm{AR}(2)$ in levels) & & & & 0.949 \\
\hline $\begin{array}{l}\text { Hansen test of over-identifying } \\
\text { restrictions }\end{array}$ & & & & 0.126 \\
\hline
\end{tabular}

Notes: $\ln$ stands for the natural logarithm and $l$. for a variable lagged by one period. The dependent variable $\ln$ TFP is derived econometrically (see Section 3.1 above). In column (4), the export share of production and import penetration are treated as potentially endogenous (lags 2-5), the first lags of TFP and R\&D spending are treated as predetermined (lags 1-4), while the other variables are treated as strictly exogenous. Robust standard errors in brackets; Standard errors are clustered at the country $\times$ year level in column (3) and at the industry $\times$ country level in columns (1)-(2); * significant at $10 \%$; ${ }^{* *}$ significant at $5 \%$; ${ }^{* * *}$ significant at $1 \%$.

at the level of the eleven manufacturing sectors contained in our sample. For each industry, the ME was obtained as a weighted average of the country-sector specific MEs evaluated at $\bar{w}_{i c}$, which is the sampleperiod average log of the deviation from average labour compensation for industry $\mathrm{i}$ and country c. ${ }^{10}$ The weights were based on the average value of output of each country $\times$ sector pair.

The MEs of energy taxes on productivity is positive in up to five sectors. This seems to pick up adaptation processes generating unforeseen gains (if they had been foreseen, they would have been uncorrelated to energy tax shocks). Figs. 4 to 6 show that at least two of the MEs computed at the sectoral level are significantly positive. The two sectors "coke, refined petroleum products and nuclear fuel" and "chemicals and chemical products" seem to be able to adapt to energy taxes as predicted by the Porter hypothesis. The deviation from average labour compensation for these sectors is greater than $50 \%$ meaning that the average employee in these industries earns a wage more than 50\% higher than the manufacturing average.

At the opposite, there is also some evidence that up to three sectors will be harmed by higher energy taxes because of their insufficient adaptive capacity. In fact, the average labour compensation per

\footnotetext{
${ }^{10}$ Evaluated at $\bar{w}_{i c}$, the overall effect of higher energy taxes on TFP is positive for $46 \%$ of the country-sector pairs included in our sample.
}

Table 4

Robustness runs: using the price-cost margin and natural gas taxes and prices as independent variables and net trade as dependent variable.

\begin{tabular}{|c|c|c|c|c|c|}
\hline \multirow[t]{2}{*}{ Variables } & \multirow{2}{*}{$\begin{array}{l}(1) \\
\text { Fixed } \\
\text { effects }\end{array}$} & \multirow{2}{*}{$\begin{array}{l}\text { Fixed } \\
\text { effects }\end{array}$} & \multirow{2}{*}{$\frac{(3)}{\begin{array}{l}\text { Random } \\
\text { effects }\end{array}}$} & \multirow{2}{*}{$\begin{array}{l}\text { Fixed } \\
\text { effects }\end{array}$} & \multirow{2}{*}{$\begin{array}{l}\text { Fixed } \\
\text { effects }\end{array}$} \\
\hline & & & & & \\
\hline Dep. Var.: & $\ln$ TFP & $\ln$ TFP & $\ln \mathrm{X} / \mathrm{M}$ & $\ln \mathrm{X} / \mathrm{M}$ & $\ln \mathrm{X} / \mathrm{M}$ \\
\hline Energy carrier: & NG & $\mathrm{AD}$ & $\mathrm{AD}$ & $A D$ & $\mathrm{AD}$ \\
\hline ln Export Share & $\begin{array}{l}-0.13 \\
{[0.12]}\end{array}$ & $\begin{array}{l}-0.058 \\
{[0.11]}\end{array}$ & & & \\
\hline In Import Pen. & -0.20 & $\begin{array}{l}-0.15 \\
{[0.12]}\end{array}$ & & & \\
\hline In Labour comp. & $\begin{array}{l}-3.63 \\
{[2.16]}\end{array}$ & $\begin{array}{l}1.44^{* * * *} \\
{[0.49]}\end{array}$ & $\begin{array}{l}2.09^{* * *} \\
{[0.44]}\end{array}$ & $\begin{array}{l}2.19^{* * *} \\
{[0.48]}\end{array}$ & $\begin{array}{l}1.38 \\
{[0.84]}\end{array}$ \\
\hline 1.In R\&D spendings & $\begin{array}{l}0.058^{* *} \\
{[0.027]}\end{array}$ & $\begin{array}{l}0.052 \\
{[0.038]}\end{array}$ & $\begin{array}{l}0.018 \\
{[0.023]}\end{array}$ & $\begin{array}{l}0.019 \\
{[0.025]}\end{array}$ & $\begin{array}{l}-0.043 \\
{[0.028]}\end{array}$ \\
\hline ln Output & $\begin{array}{l}0.31^{* * *} \\
{[0.098]}\end{array}$ & $\begin{array}{l}0.23^{* * *} \\
{[0.081]}\end{array}$ & $\begin{array}{l}0.22^{* * *} \\
{[0.073]}\end{array}$ & $\begin{array}{l}0.30^{* * *} \\
{[0.090]}\end{array}$ & $\begin{array}{l}1.21^{* * *} \\
{[0.083]}\end{array}$ \\
\hline ln Nbr. of Estab. & $\begin{array}{l}-0.068 \\
{[0.052]}\end{array}$ & & $\begin{array}{l}0.033^{*} \\
{[0.017]}\end{array}$ & $\begin{array}{l}0.036^{*} \\
{[0.020]}\end{array}$ & $\begin{array}{l}0.17^{* * *} \\
{[0.048]}\end{array}$ \\
\hline $\ln \mathrm{PCM}$ & & $\begin{array}{l}3.16^{* * *} \\
{[0.60]}\end{array}$ & & & \\
\hline ln US Exch. Rate & $\begin{array}{l}0.82^{* * * *} \\
{[0.28]}\end{array}$ & $\begin{array}{l}0.36^{* * *} \\
{[0.10]}\end{array}$ & $\begin{array}{l}0.064 \\
{[0.058]}\end{array}$ & $\begin{array}{l}0.28 \\
{[0.19]}\end{array}$ & \\
\hline ln Taxes & $\begin{array}{l}-2.05^{* * *} \\
{[0.45]}\end{array}$ & $\begin{array}{l}-5.52^{* * *} \\
{[1.46]}\end{array}$ & $\begin{array}{l}-5.01^{* * *} \\
{[1.52]}\end{array}$ & $\begin{array}{l}-4.78^{* * *} \\
{[1.57]}\end{array}$ & \\
\hline ln Price net of taxes & $\begin{array}{l}-2.43 \\
{[2.10]}\end{array}$ & $\begin{array}{l}-1.01 \\
{[0.73]}\end{array}$ & $\begin{array}{l}-2.79^{* *} \\
{[1.17]}\end{array}$ & $\begin{array}{l}-2.88^{* *} \\
{[1.27]}\end{array}$ & \\
\hline ln Taxes $\times$ ln Labour comp. & $\begin{array}{l}0.47^{* * *} \\
{[0.095]}\end{array}$ & $\begin{array}{l}1.19^{* * *} \\
{[0.32]}\end{array}$ & $\begin{array}{l}1.09^{* * *} \\
{[0.32]}\end{array}$ & $\begin{array}{l}1.04^{* * *} \\
{[0.34]}\end{array}$ & $\begin{array}{l}-0.50 \\
{[0.58]}\end{array}$ \\
\hline $\begin{array}{l}\text { In Price net of taxes } \times \ln \\
\text { Labour comp. }\end{array}$ & 0.49 & 0.24 & $0.57^{* *}$ & $0.57^{* * *}$ & $0.78^{*}$ \\
\hline & {$[0.43]$} & {$[0.17]$} & {$[0.24]$} & {$[0.26]$} & {$[0.43]$} \\
\hline Industry FE & no & no & no & no & yes \\
\hline Country FE & no & no & no & no & no \\
\hline Industry $\times$ Country FE & yes & yes & no & yes & no \\
\hline Country $\times$ Year FE & no & no & no & no & yes \\
\hline Year FE & yes & yes & yes & yes & no \\
\hline Observations & 298 & 466 & 466 & 466 & 466 \\
\hline R-squared & 0.873 & 0.911 & 0.0059 & 0.982 & 0.711 \\
\hline Prob > chi2 (Hausman test) & $<0.0001$ & & & 0.434 & \\
\hline
\end{tabular}

Notes: In stands for the natural logarithm, $l$. for a variable lagged by one period, NG for natural gas and $\mathrm{AD}$ for automotive diesel. Robust standard errors in brackets; Standard errors are clustered at the country $\times$ year level in column (5) and at the industry $\times$ country level in columns (1)-(4); * significant at $10 \%$; ${ }^{* *}$ significant at $5 \%$; ${ }^{* * *}$ significant at $1 \%$.

employee for these sectors lies around or below $80 \%$ of the manufacturing average. These three sectors are the food products, beverages, tobacco sector, the manufacturing n.e.c. and recycling sector, the wood, wood and corn products sector. In between these two extremes, the effect of energy taxes is quite uncertain or negligible for four out of the eleven manufacturing sectors contained in our sample.

It might be argued that the most energy and pollution intensive industries also have the most to benefit from adapting to higher energy prices. This might not be adaptive capacity but simply a necessity to cope with higher energy prices. Unfortunately we were not able with the available data to precisely identify the energy intensive sectors in our sample. In the international trade literature, the following sectors are usually considered to be energy intensive: Paper and products, Industrial chemicals, Other non-metallic mineral products, Iron and steel, Non-ferrous metals (refinery products are usually excluded). These sectors do not form a compact group in Figs. 4 to 6 .

Overall we find that it is important to take into account industry adaptability when identifying the effect of energy taxes on industry performance. While some industries can even benefit from increased energy taxes, others, mainly low wage sectors, can see their performance decrease.

\section{Conclusion and policy implications}

On the basis of a panel of industries tracked for six European countries over more than ten years, we find that the impact of rising 


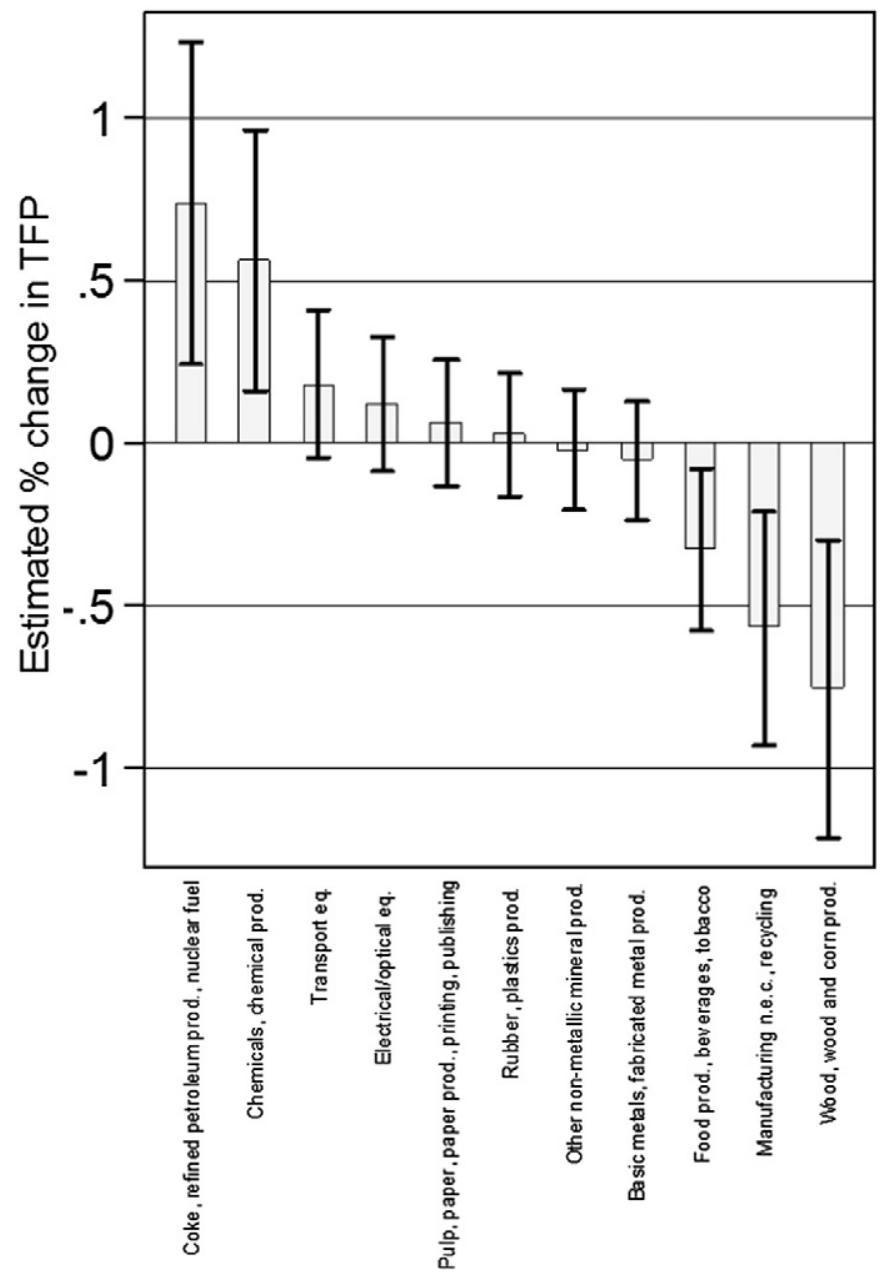

Fig. 4. Marginal effects of energy taxes on TFP: estimated percentage change in sectoral total factor productivity when energy taxes on automotive diesel rise by $1 \%$ (preferred FE model).

energy taxes on TFP and net trade is industry-specific. This confirms previous findings in the literature. We find that the impact depends upon the adaptive capacity of each manufacturing industry which is measured in this paper by their relative level of labor compensation. For high-wage industries, the adaptation effect is strong enough to produce significant increases in TFP and net trade. The inclusion of a full set of industry $\times$ country fixed effects ensures that the measured effect is "within-industry" and not driven by unobserved heterogeneity.

It is likely that industries with relatively high labor compensation reflect the reactivity to energy-tax shocks and the active search for more efficient processes, whether through true knowledge creation, knowledge absorption, or better organization. Could it be driven by a selection effect? In the long run, higher energy taxes are likely to induce the exit of the least productive firms in each industry; in addition, only the most productive ones could afford the fixed costs and risks of higher R\&D spending or to pay for the most skilled workers. Thus, energy-tax shocks might be expected to partition firms, with the most productive investing to reduce energy costs, the middle ones simply suffering reduced profitability, and the least productive ones exiting. This could produce a rise in industry-wide average productivity. Only firm-level analysis could tell whether this selection (between-firm) process is at play and whether it is the most important quantitatively. However, it is a long-run phenomenon that is unlikely to be driving the contemporaneous effects that we identify so strongly in the industry-level data.

The policy implications of our finding are intuitive but potentially important. Emission-regulation shocks, inasmuch as they raise the cost associated with the use of fossil fuels, can be expected to have a negative effect

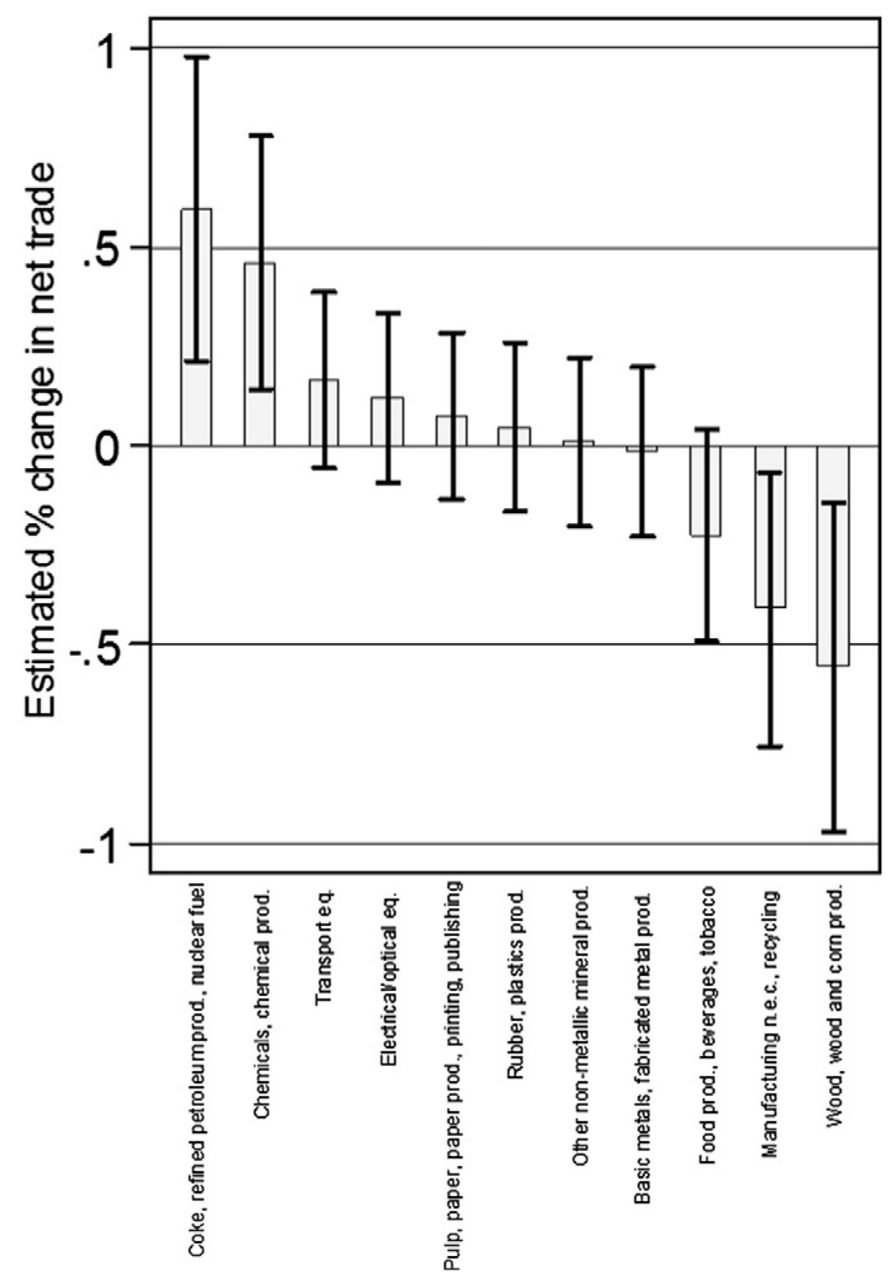

Fig. 5. Marginal effects of energy taxes on net trade: estimated percentage change in sectoral net trade when energy taxes on automotive diesel rise by $1 \%$ (preferred RE model).

on competitiveness, but a positive one for those industries with the highest capacity to adapt, as proxied by their labor expenditures. This suggests a policy aimed at improving the capacity of firms to adapt through higher qualifications prior to the adoption of stiff emission standards. If effective, this could turn subsequent environmental regulation into the kind of win-win situation that Porter and van der Linde (1995) identified.

Several questions of interest are left for future research. First, in order to refine our understanding of the mechanisms at work it is crucial to identify the deeper reasons for the linkages between adaptive capacity and the response of industries to energy taxes. With which concrete measures do firms with high adaptive capacity mitigate the adverse effects of energy taxes? To answer this question more detailed firm level data are necessary. Second, what would be needed to help industries with low adaptive capacity to turn high energy prices into a winning situation for them? This would help to increase the political acceptance of progressive energy policies. Third, most studies focus on high income countries, but energy taxes are also commonly applied in developing countries, although rather to fill government budgets than for climate policy reasons. Would the present conclusions hold for industries in developing countries? These research avenues should be investigated in the future.

\section{Acknowledgements}

The authors gratefully acknowledge the support of the Swiss Federal Office of Energy (SFOE) and thank Jean-Marie Grether for helpful comments. 


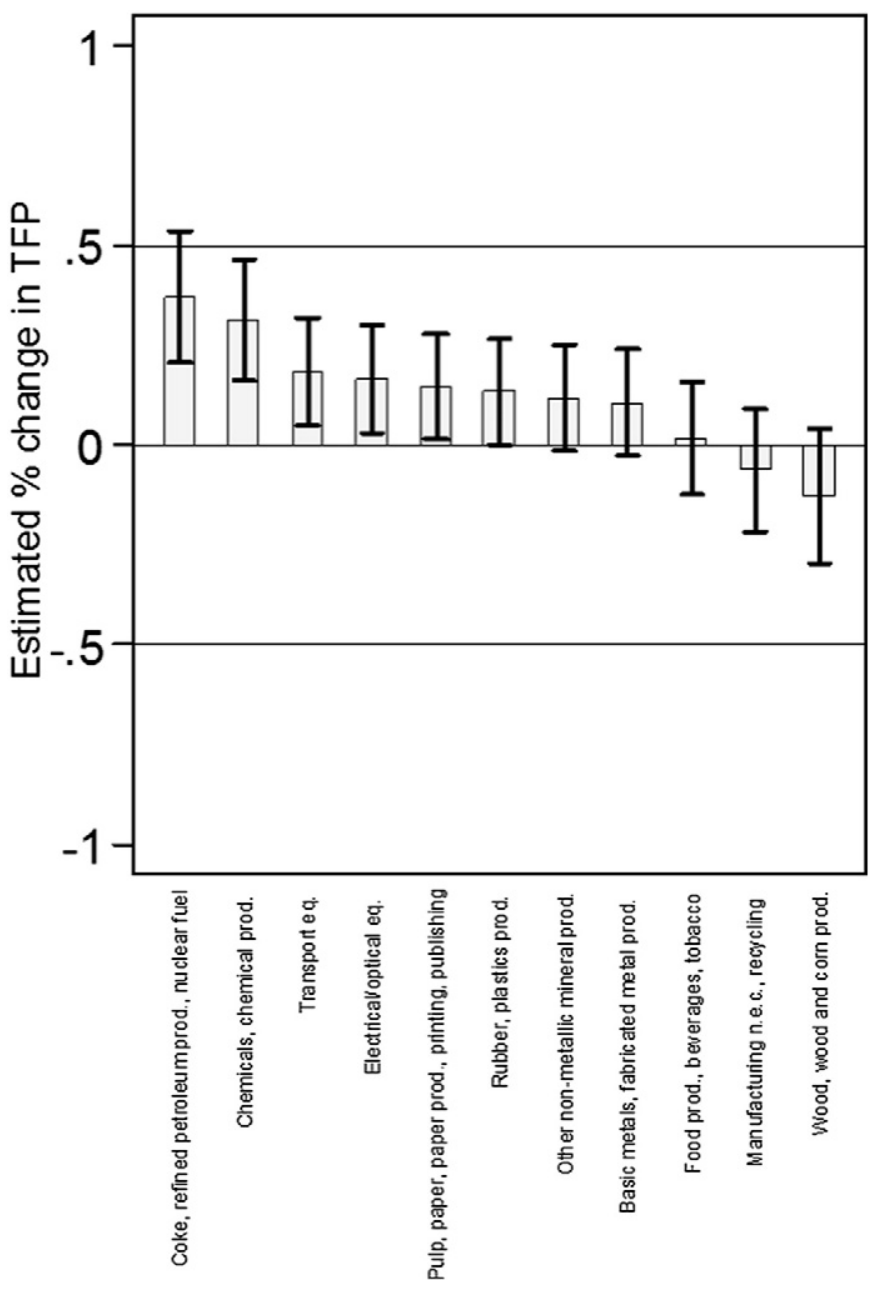

Fig. 6. Marginal effects of energy taxes on TFP: estimated percentage change in sectoral total factor productivity when energy taxes on natural gas rise by $1 \%$ (preferred FE model).

\section{Appendix A. Supplementary data}

Supplementary data to this article can be found online at http://dx. doi.org/10.1016/j.eneco.2014.12.010.

\section{References}

Albrecht, J.A.E., 1998. Environmental costs and competitiveness: a product-specific test of the Porter Hypothesis. Working Paper Nr. 98/50. University of Ghent.

Ambec, S., Barla, P., 2002. A theoretical foundation of the Porter Hypothesis. Econ. Lett. 75, 355-360.

Ambec, S., Cohen, M.A., Elgie, S., Lanoie, P., 2013. The Porter Hypothesis at 20: can environmental regulation enhance innovation and competitiveness? Rev. Environ. Econ. Policy 7 (1), 2-22.

Baranzini, A., Weber, S., 2013. Elasticities of gasoline demand in Switzerland. Energy Policy $36,674-680$

Battisti, G., Canepa, A., Stoneman, P., 2009. e-Business usage across and within firms in the UK: profitability, externalities and policy. Res. Policy 38 (1), 133-143.

Becker, R., Henderson, V., 2000. Effects of air quality regulations on polluting industries. J. Polit. Econ. 108, 379-421.

Berman, E., Bui, L.T.M., 2001. Environmental regulation and productivity: evidence from oil refineries. Rev. Econ. Stat. 83, 498-510.

Berndt, E., Wood, D., 1986. Energy price shocks and productivity growth in US and UK manufacturing. Oxf. Rev. Econ. Policy 2, 1-31.

Boulhol, H., 2008. The convergence of price-cost margins, Open Econ. Rev. 19 (2), 221-240.

Brunnermeier, S., Cohen, M., 2003. Determinants of environmental innovation in US manufacturing industries. J. Environ. Econ. Manag. 45, 278-293.

Commins, N., Lyons, S., Schiffbauer, M., Tol, R., 2011. Climate policy and corporate behaviour. Energy J. 32, 51-68.

Copeland, A., Kahn, J.A., 2012. Exchange rate pass-through, markups and inventories. Working paper at Federal Reserve Bank of New York.

Davis, L., Kilian, L., 2011. Estimating the effect of a gasoline tax on carbon emissions. J. Appl. Econ. 26, 1187-1214.
DeCanio, S., 1993. Barriers within firms to energy-efficient investments. Energ Policy 21, 906-914.

Edin, P.-A., Zetterberg, J., 1992. Interindustry wage differentials: Evidence from Sweden and a comparison with the United States. Am. Econ. Rev. 82 (5), 1341-1349.

Enervoldsen, M.K., Ryelund, A., Andersen, M.S., 2009. The impact of energy taxes on competitiveness: A panel regression study of 56 European industry sectors. In: Andersen, M.S., Ekins, P. (Eds.), Carbon-energy taxation: Lessons from Europe. Oxford University Press, New York, pp. 100-119.

Gabel, L., Sinclair-Desgagné, B., 1993. Managerial incentives and environmental compliance. J. Environ. Econ. Manag. 24, 940-955.

Gabel, L., Sinclair-Desgagné, B., 2001. The firm, its procedures, and win-win environmental regulations. In: Folmer, H., Gabel, L., Gerking, S., Rose, A. (Eds.), Frontiers of environmental economics. Edward Elgar, pp. 148-175.

Gibbons, R., Katz, L.F., Lemieux, T., Parent, D., 2005. Comparative advantage, learning, and sectoral wage determination. J. Labour Econ. 23 (4), 681-724.

Gollop, F., Roberts, M., 1983. Environmental regulation and productivity growth: the case of fossil-fueled electric power generation. J. Polit. Econ. 91, 654-674.

Gray, W., Shadbegian, R., 1998. Environmental regulation, investment timing, and technology choice. J. Ind. Econ. 46, 235-256.

Greenstone, M., 1998. The marginal effects of environmental regulations of the manufacturing sector: evidence from the 1970 and 1977 Clean Air Act Amendments. Mimeograph, Princeton University Department of Economics (July).

Griffith, R., Redding, S., Van Reenen, J., 2004. Mapping the two faces of R\&D: productivity growth in a panel of OECD industries. Rev. Econ. Stat. 86, 883-895.

Hall, B.H., 2006. Innovation and diffusion. In: Fagerberg, J., Mowery, D.C., Nelson, R.R. (Eds.), The Oxford handbook of innovation. Oxford University Press, Oxford and New York (chapter 17)

Hall, B.H., Khan, B., 2003. Adoption of new technology. In: Jones, D.C. (Ed.), New economy handbook. Academic Press, San Diego, pp. 229-249.

INFRAS, 2007. Erfahrungen mit Energiesteuern in Europa - Lehren für die Schweiz. INFRAS, Zurich, Switzerland.

Jaffe, A., Palmer, K., 1997. Environmental regulation and innovation: A panel data study. Rev. Econ. Stat. 79, 610-619.

Jaffe, A., Stavins, R., 1995. Dynamic incentives of environmental regulations: The effects of alternative policy instruments on technology diffusion. J. Environ. Econ. Manag. 29, 43-63.

Jaffe, A., Peterson, S., Portney, P., Stavins, R., 1995. Environmental regulations and the competitiveness of U.S. manufacturing: what does the evidence tell us? J. Econ. Lit. 33, 132-163

Jaffe, A., Newell, R., Stavins, R., 2003. Technological change and the environment. In: Mäler, K.G., Vincent, J.R. (Eds.), Handbook of environmental economics. vol. 1. Elsevier, pp. 461-516.

Joshi, S., Lave, L., Shih, J.-S., McMichael, F., 1997. Impact of environmental regulations on the U.S. steel industry. Carnegie Mellon University, Pittsburgh.

Kilian, L., 2008. The economic effects of energy price shocks. J. Econ. Lit. 46 (4), 871-909.

Kniesner, Th., Leeth, J.D., 1991. Compensating wage differentials for fatal injury risk in Australia, Japan, and the United States. J. Risk Uncertain. 4 (1), 75-90.

Lanjouw, J., Mody, A., 1996. Innovation and the international diffusion of environmentally responsive technology. Res. Policy 25, 549-571.

Lanoie, P., Patry, M., Lajeunesse, R., 2008. Environmental regulation and productivity: testing the Porter Hypothesis. J. Prod. Anal. 30, 121-128.

Lanoie, P., Laurent-Lucchetti, J., Johnstone, N., Ambec, S., 2011. Environmental policy, innovation and performance: new insights on the Porter Hypothesis. J. Econ. Manag. Strategy 20, 803-842.

Li, Sh., Linn, J., Muehlegger, E., 2012. Gasoline taxes and consumer behavior. NBER Working Paper 17891. National Bureau of Economic Research Inc.

Lovins, A., 1996. Negawatts. Energ Policy 24, 331-343.

Mohr, R.D., 2002. Technical change, external economies, and the Porter Hypothesis. J. Environ. Econ. Manag. 43, 158-168.

Morgenstern, R.D., Pizer, W.A., Shih, J.-S., 1999. The cost of environmental protection. Resources for the Future, Washington.

Murti, M., Kumar, S., 2003. Win-win opportunities and environmental regulation: testing of Porter Hypothesis for Indian manufacturing industries. J. Environ. Econ. Manag. 67, 139-144.

Nelson, R., Winter, S., 1982. An evolutionary theory of economic change. Harvard University Press.

Nickell, S.J., 1996. Competition and corporate performance. J. Polit. Econ. 104 (4), 724-746.

Palmer, K., Oates, W., Portney, P., 1995. Tightening environmental standards: the benefitcost or the no-cost paradigm? J. Econ. Perspect. 9, 119-132.

Popp, D., 2002. Induced innovation and energy prices. Am. Econ. Rev. 92, 160-180.

Porter, M., 1991. America's green strategy. Sci. Am. 264 (4), 168.

Porter, M., van der Linde, C., 1995. Toward a new conception of the environmentcompetitiveness paradigm. J. Econ. Perspect. 9, 97-118.

Rajan, R., Zingales, L., 1998. Financial dependence and growth. Am. Econ. Rev. 88, 559-586.

Rose, N., Joskow, P., 1990. The diffusion of new technologies: evidence from the electric utility industry. RAND J. Econ. 21, 354-373.

Rosenberg, N., 1972. Factors affecting the diffusion of technology. Explor. Econ. Hist. 10 (1), 3-33.

Reprinted inRosenberg, N., 1976. Perspectives on technology. Cambridge University Press, Cambridge, pp. 189-212

Shadbegian, R., Gray, W., 2005. Pollution abatement expenditures and plant-level productivity: a production function approach. Ecol. Econ. 54, 196-208.

Snyder, L., Miller, N., Stavins, R., 2003. The effects of environmental regulation on technology diffusion: the case of chlorine manufacturing. Am. Econ. Rev. 93, 431-435.

Vollebergh, H.R.J., 2006. Differential impact of environmental policy instruments on technological change: a review of the empirical literature. Tinbergen Institute Discussion Papers 07-042/3. Tinbergen Institute. 